\title{
Evaluation of the use of topic nasal decongestants in university students from health sciences courses
}

\author{
Dominik Lenz ${ }^{1,2}$, Kézia Santos Cardoso ${ }^{1}$, Ana Carla Rangel Bitti ${ }^{1}$, Tadeu Uggere Andrade ${ }^{1, *}$ \\ ${ }^{1}$ Departament of Pharmacy, University of Vila Velha, ${ }^{2}$ Department of Veterinary Medicine, University of Vila Velha
}

\begin{abstract}
Nasal decongestants in Brazil are available without prescription. They are one of the most requested medications in Brazil. The use of nasal decongestants, however, may lead to serious consequences. For this study, university students majoring in the health field were evaluated in terms of their profile regarding the use of nasal decongestants. Additionally, health sciences seniors were evaluated regarding their level of knowledge concerning the correct and proper use of nasal decongestants. Among the $71.8 \%$ of respondents who had already used topic nasal decongestants, $64.3 \%$ had used this medication for at least 15 days and $64.6 \%$ had started using it due to nasal obstruction. The gathered data indicate that the pharmacist was the main health professional reported as having provided patients with guidance on how to use this medication. A five-point Likert Type intensity scale $(3.6 \pm 0.08)$ shows that a regular level of knowledge has been observed among the students. Most of the students polled were concluded to incorrectly use topic nasal decongestants. Furthermore, the results of this study indicate that the future health professionals are not well prepared to promote health education for patients concerning the rational use of nasal decongestants.
\end{abstract}

Uniterms: Nasal decongestans/use evaluation. Self-prescribed medication. Health education.

Os descongestionantes nasais representam um dos grupos de medicamentos mais procurados dentro da automedicação no Brasil e as consequências ocasionadas pelo uso prolongado podem ser graves. Neste estudo foi aplicado a universitários da área de saúde um instrumento de avaliação para coleta de informações relacionadas ao perfil do uso destes medicamentos e outro instrumento para os alunos do último ano destas áreas para avaliar o nível de conhecimentos sobre o uso racional e correto dos descongestionantes nasais. Dos acadêmicos entrevistados, $71,8 \%$ fazem ou já fizeram o uso de descongestionantes nasais tópicos e destes, $64,3 \%$ utilizaram o medicamento por menos de 15 dias; $64,6 \%$ iniciaram o uso do descongestionante devido à obstrução nasal. Os dados obtidos ainda mostraram o farmacêutico como principal profissional responsável pela orientação do uso do medicamento aos usuários. Foi observado nível de conhecimento regular por parte dos alunos, através da escala de intensidade de cinco pontos do tipo Likert $(3,6 \pm 0,08)$. Conclui-se pelo uso incorreto de descongestionantes nasais tópicos pela maioria dos entrevistados e que falta preparo aos futuros profissionais para correta educação aos pacientes.

Unitermos: Descongestionantes nasais/avaliação do uso. Automedicação. Educação em saúde.

\section{INTRODUCTION}

Decongestants are drugs that can act as sympathomimetic agents. They cause local vasoconstriction, thereby reducing congestion and edema of the nasal mucosa (Smith, Aronson, 2004). They are used to advance nasal

\footnotetext{
*Correspondence: T. U. Andrade. Departamento de Farmácia, Centro Universitário Vila Velha. Rua Comissário José Dantas de Melo, 21 - Boa Vista - 29102-770 - Vila Velha - ES, Brazil. E-mail: tadeu.andrade@uvv.br
}

obstruction in the common cold, sinusitis, fever, acute or chronic rhinitis, allergies of the upper respiratory tract, deviated septum, turbinate hypertrophy, nasal polyps and cancers (Zafanni et al., 2007).

Allergic rhinitis is one of the clinical situations in which nasal decongestants are used. It is a disease that affects about $10 \%$ to $20 \%$ of the world population and $15 \%$ to $25 \%$ of children and adolescents (Castro, 2003).

Among the sympathomimetic vasoconstrictors for local application in the nose, imidazoles (naphazoline, 
oxymetazoline, and xylometazoline) and catecholamine derivatives (epinephrine, ephedrine, and phenylephrine) are differentiated (Balbani et al., 2002). Both groups of nasal decongestants produce vasoconstriction by stimulation through the endogenous release of noradrenaline, which acts on alpha receptors (Corboz et al., 2008).

However, prolonged use of nasal decongestants leads to side effects, e.g. iatrogenic rhinitis. Therefore, the local application of vasoconstrictors may be used only for short periods of time (Bricks, Sih, 1999), and should not be used longer than four or five days, due to the risk of mucosal injury and rebound vasodilation (Arnold, 1992). In addition, prolonged use of decongestants leads to decreased sensitivity of alpha receptors, leading to a requirement of higher doses in shorter intervals in order to reach the same effect. Consequently, patients have started to use excessive doses of nasal decongestants (Doshi, 2008).

In Brazil, decongestants are a group of drugs most sought by patients for self-medication (Arrais et al., 1998). Self-medication becomes even more risky due to the fact that the population is poorly educated in regard to drugs and their correct use. Moreover, there is a lack of involvement by health professionals who could offer guidance to users (Servidoni et al., 2006).

According to the Brazilian Association of Pharmaceutical Industries, millions of people self-medicate; this is mainly due to the fact that many drugs can be purchased without prescription. Concerning nasal decongestants, a possible reason why so many abuse them is the fast efficiency of the drug ("personal experience") (Bricks, 1995).

Additionally, the widespread availability and ease for purchasing the drug in pharmacies is another factor contributing to the inadequate use of nasal decongestants (Zafanni et al., 2007). This may have consequences for users, e.g., side effects, iatrogenic problems and progressive diseases. These processes have become a public problem to be identified and prevented (Servidoni et al., 2006).

Drugstore clerks offer advice on how to treat diseases most frequently. This practice is routinely observed in cases of respiratory diseases, in which the clerk prescribes medicines without proper knowledge of the indications, contraindications, dosage, adverse effects and possible drug interactions (Balbani, Sanchez, Butugan, 1996; Balbani et al., 1996). Thus, self-medication and lack of information on nasal decongestants may endanger the health of its users.

The aim of this study was, therefore, to determine the frequency and character of the use of nasal decongestants in college health care. In addition, we assessed the level of knowledge about the rational use of these drugs in the last academic year of courses in this area.

\section{METHODS}

We conducted a cross-sectional study of quantitative and qualitative nature involving the academic health students of a higher education institution in the state Espírito Santo, Brazil, between June and September 2009. Data was collected by using structured questionnaires.

\section{Sample calculation}

The survey was conducted with students of medicine, pharmacy, nutrition, nursing, speech therapy, physiotherapy and physical education, through the stratified probabilistic method, in which the calculation of the sample was designed considering a confidence level of $95 \%$ and a $5 \%$ sample error. For this study, data was gathered from 383 students. The assessment tools were administered after all subjects had fully agreed and signed the consent form.

\section{Evaluation of the frequency and profile of users}

Through assessment tool I, the socio-economiccultural stage was calculated using parameters like sex, age, current occupation, and family income. The students answered questions related to the drug, e.g., habits of use, frequency of use, and reasons to use the drug.

During the last academic year, assessment tool II was also applied; it contained statements about the decongestants. The questionnaire assessed the level of technical knowledge these students possessed in terms of the rational use of nasal decongestants. True and false statements were presented to the students. The scale used in this tool consisted of a five-point Likert Type scale of intensity; the lowest number stands for "absolutely false" and the highest option means "absolutely true". For the false statements, there was an inversion of the values for the calculation of the final score, e.g., if a student assigned a score of 1 to a false assertion, which was the correct answer; the score was then converted to five points.

From the data obtained by the questionnaires, the profile of the rational use of nasal decongestants and the level of knowledge of students from the last year of health care courses was determined.

\section{Statistical analysis}

The data were compiled into a spreadsheet developed in Microsoft Excel (Microsoft Office 2007). The data were analyzed using the SPSS Statistical Package Social Science version 11.5 (SPSS 11.5), where it performed 
relative frequencies and simple cross. For the quantitative analysis, a one-way analysis of variance (ANOVA) was performed. The post-hoc test was used for Fisher's multiple comparisons with a randomized design. These data were expressed as mean \pm standard error of mean (S.E.M.).

\section{RESULTS AND DISCUSSION}

For this study, 383 students were interviewed, $71.8 \%$ $(n=275)$ of which had already made use of topical nasal decongestants. The gender breakdown of the student sample was $76.7 \%(n=211)$ female and $23.3 \%(n=64)$ male. Mean age was $22 \pm 1$ years. The majority of the users had an income of five times the minimum wage or more $(49.6 \%, \mathrm{n}=190)$.

In Brazil, there is a high prevalence of nasal symptoms, accompanied by many prescriptions by physicians or self-medication (Balbani, Duarte, Montovani, 2004). These circumstances could explain the high percentage of subjects having already used nasal decongestants, as observed in this study. This is confirmed by the observation that nasal decongestants are among the most requested medications in Brazil, which is favored by the large supply and ease for purchasing this product freely in pharmacies and drugstores (Zafanni et al., 2007).

Taking only those patients who were or had been using nasal decongestant $(71.8 \%, \mathrm{n}=275)$ into account, the duration of decongestant use was less than 15 days, followed by 15 days to a month (Table I). The highest frequency of use was seen in subjects who displayed symptoms of disease. The majority of these used it once per day (Table II).

TABLE I - Duration of nasal decongestant use among the participants

\begin{tabular}{lcc}
\hline Duration of use & Quantity (n) & Percentage (\%) \\
\hline Less than 15 days & 178 & 64.7 \\
15 to 30 days & 39 & 14.2 \\
2 to 6 months & 14 & 5.1 \\
7 to 12 months & 9 & 3.3 \\
2 to 5 years & 11 & 4.0 \\
more than 5 years & 24 & 8.7 \\
\hline
\end{tabular}

The majority of users was experiencing symptoms and this could explain why decongestants are used for a long time, i.e., longer than the maximum of four to five days as suggested by Arnold (1992), at least. However, it is alarming to notice that $35.3 \%(\mathrm{n}=97)$ of respondents have used decongestants for more than 15 days, with a
TABLE II - Frequency of use of nasal decongestant

\begin{tabular}{lcc}
\hline Frequency of use & Quantity $(\mathrm{n})$ & Percentage $(\%)$ \\
\hline Once per day & 40 & 14.5 \\
Twice per day & 37 & 13.5 \\
3 times per day & 37 & 13,5 \\
4 time per day & 13 & 4.7 \\
5 or more times per day & 8 & 2.9 \\
Only with symptoms & 130 & 47.3 \\
Others & 10 & 3.6 \\
\hline
\end{tabular}

substantial share of $12.7 \%(\mathrm{n}=35)$ having used it for more than two years. The latter patients are obviously endangered, as the chronic use of this medicine may lead to a nasal congestion rebound effect and its prolonged use can lead to iatrogenic rhinitis (Bricks, Sih, 1999), and mucosal injury (Arnold, 1992).

A total of 25 types of medicinal topical nasal decongestants have been described. The total number of such varieties used by respondents was 416 , representing an average of 1.5 products per interviewee. Among the most cited were the adult Sorine ${ }^{\circledR}(32.2 \%, \mathrm{n}=134)$, Neosoro ${ }^{\circledR}$ $(16.5 \%, n=69)$, Rinosoro $\AA(16.5 \%, n=69)$, Afrin ${ }^{\circledR}$ $(9.1 \%, \mathrm{n}=38)$ and Children Sorine ${ }^{\circledR}(6.9 \%, \mathrm{n}=29)$.

Grouping these medicines by active ingredients, it can be observed that the most frequently used by respondents was the naphazoline hydrochloride (Adult Sorine ${ }^{\circledR}$, Neosoro ${ }^{\circledR}$, Naridrin ${ }^{\circledR}$, Adnax $\AA$ ), followed by sodium chloride (Rinosoro ${ }^{\circledR}$, Sorine Child ${ }^{\circledR}$, Sorine $\left.H ®\right)$ and oxymetazoline hydrochloride (Afrin ${ }^{\circledR}$ and Aturgyl ${ }^{\circledR}$ ) (Figure 1).

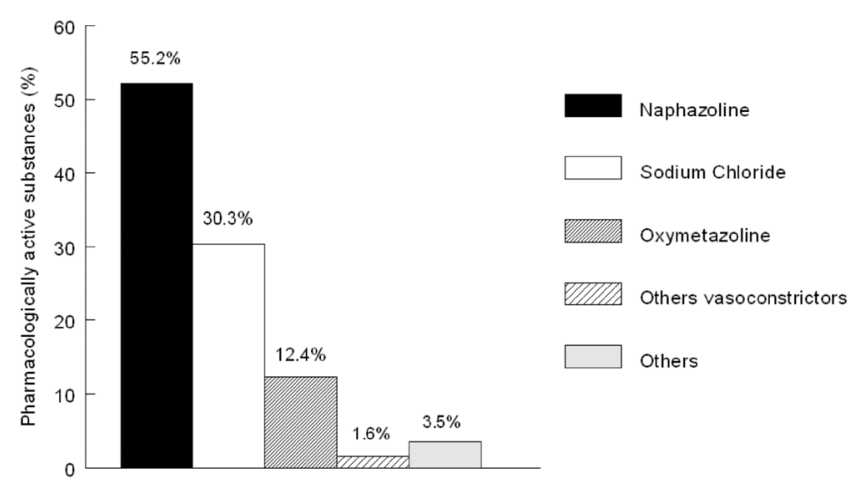

FIGURE 1 - Pharmacologically active substances used by the students interviewed.

As shown in Figure 1, 69.2\% of the active ingredients made up of vasoconstrictors such as naphazoline and oxymetazoline. This probably results from the fact that patients are seeking immediate and effective relief 
for nasal congestion, and vasoconstrictors are known to promote a rapid and prolonged effect (Weckx et al., 1983). Nevertheless, there have been reports about neuropsychiatric effects caused by sympathomimetic amines found in systemic and topical decongestants (Balbani et al., 1997).

Products containing sodium chloride represent the second most nasal decongestants used by respondents. They offer advantages such as cleaning, removal of secretions and reduction of local mucosal edema (Viertler et al., 2003) without the disadvantages described above for vasoconstrictors, and are therefore identified as a more rational alternative.

It was found that among the reasons for early use of the drug, nasal obstruction was the most frequent (Table III). Nasal obstruction is the most common symptom in patients with allergic rhinitis, a disease that affects a large percentage of the population, especially children and adolescents, with a clinical situation where decongestants are used for providing quick relief (Castro, 2003).

TABLE III - Reasons for the use of nasal decongestants

\begin{tabular}{lcc}
\hline Reasons for use & Quantity $(\mathrm{n})$ & Percentage (\%) \\
\hline Nasal obstruction & 179 & 65.0 \\
Coryza & 26 & 9.5 \\
Sneezing & 12 & 4.4 \\
Itching nose & 2 & 0.7 \\
Others & 17 & 6.2 \\
More than one reason & 39 & 14.2 \\
\hline
\end{tabular}

Figure 2 shows the frequency distribution of who had recommended the nasal decongestant. Friends and relatives were accounted for $29 \%(n=80)$ of recommendations. In $57 \%(\mathrm{n}=156)$ of cases, the statement was made by a health professional, mostly by a physician. Thus, one

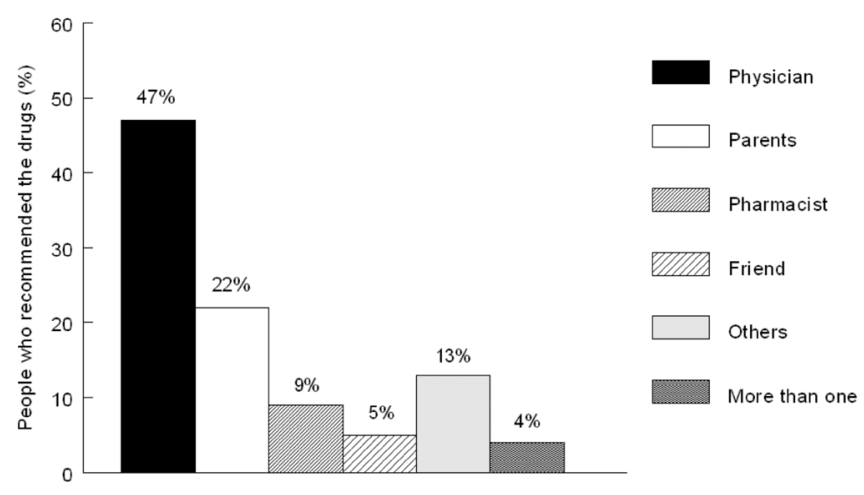

FIGURE 2 - Percentage of people who had recommended the drugs to users. can verify that the drug had been prescribed by physicians in $47.0 \%(n=130)$ of cases, $68.5 \%(n=87)$ of which had offered guidance on how to use the drug.

A large proportion of the users was treated by family members, which is understandable, from an economic perspective. However, the indication by others can cause problems like inadequate treatment, dissemination of inaccurate information, exposure to side effects, and encouragement of prolonged use of medications, which may lead to serious consequences (Arrais et al., 1998).

Another result of this study was that not many users consulted pharmacists for advice. Therefore, this study also provides information about indications, contraindications, side effects and drug interactions. Clerks participated substantially more frequently than pharmacists (Figure 2), but clerks do not often provide adequate advice to patients (Fields et al., 1985).

Among all users $(n=275)$ of nasal decongestants, $65.3 \%(n=181)$ had not received any guidance on how to use the drug. Among those who had not received guidance, $56.9 \%(n=99)$ had not followed the label directions for use of these drugs. The remaining $33.9 \%(n=94)$ had received guidance, and the pharmacist, when compared to other professionals, showed the highest percentage of participation (Table IV). The main place where the decongestant was bought was the pharmacy $(90.3 \%, \mathrm{n}=250)$ (Figure 3 ).

TABLE IV - Persons who had offered advice on how to use nasal decongestants

\begin{tabular}{lc}
\hline Person who offered guidance & Percentage $(\%)$ \\
\hline Nurse & $2.10(\mathrm{n}=3)$ \\
Pharmacist & $60.00(\mathrm{n}=60)$ \\
Clerk & $9.02(\mathrm{n}=13)$ \\
Others & $38.88(\mathrm{n}=56)$ \\
More than one option & $8.40(\mathrm{n}=12)$ \\
\hline
\end{tabular}

The results of this study clearly indicate that there is a lack of guidance for the rational use of decongestants, as more than $50 \%$ of the respondents had been given the medication without guidance on how to use it, and had not followed directions on the label.

The present study shows evidence that the pharmacist is most frequently the person to provide guidance on the proper use of decongestants. Arrais and coworkers (2007) found that pharmacists play the most important role in yielding the information on how to correctly use a drug, both in the public and private sectors. In conclusion, their presence helps to establish favorable guidance for patients, thus avoiding the guidance of clerks, who are 


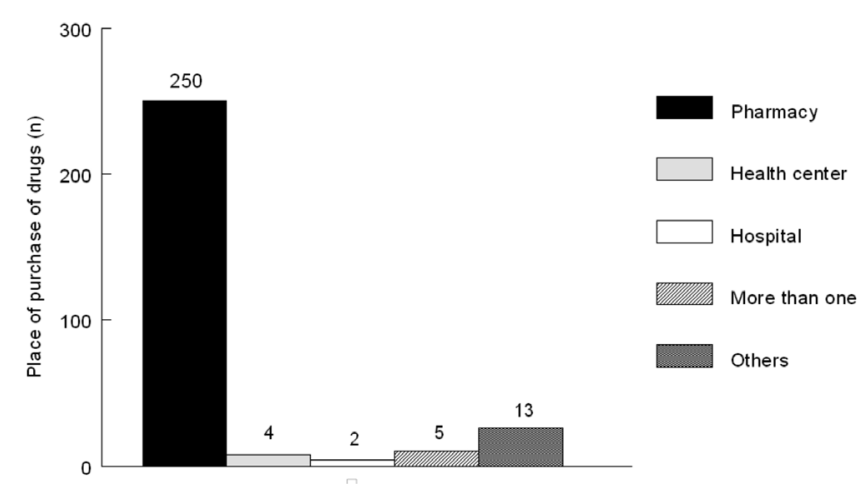

FIGURE 3 - Main sites for purchasing nasal decongestants.

no longer authorized to perform this task (Barros, 1997).

The group of respondents who had made or was making use of other drugs along with the nasal decongestant accounted for $39.7 \%(\mathrm{n}=110)$. The most used medications were analgesics (17.4\%), followed cold medicine $(16.6 \%)$, anti-thermal and antihistamine (14.2\%), followed by anti-inflammatory drugs and antibiotics $(10.3 \%)$.

It was observed that $48.7 \%(n=135)$ of users had health problems when using nasal decongestants. The main problems reported were cold / flu $(22.6 \%, \mathrm{n}=59)$, sinusitis and allergies $(16.5 \%, \mathrm{n}=43)$, rhinitis $(16.1 \%$, $\mathrm{n}=42)$ and infections and inflammations of the throat $(13.4 \%, \mathrm{n}=35)$.

It is well known that there is a wide acceptance of decongestants, topical or systemic corticosteroids, expectorants, cough suppressants and vitamins for the symptomatic treatment of colds and flu (Kennedy, Forbes, 1982). This may be the reason why of nasal decongestants - in combination with the other drugs mentioned above - are used for the main complaint reported by users. Bricks (1995) has pointed out that the associations most commonly used to treat cold/flu include decongestants and antihistamines.

Users suffering from allergic rhinitis belong to the group which typically uses nasal decongestants (Castro, 2003). Decongestants have proven useful in acute rhinitis, because its site of action is more selective, hence they tend to be abused, often resulting in rebound congestion (Gilman et al., 1996).

Among the respondents, $32.9 \%(\mathrm{n}=91)$ were aware of the dangers arising from the irrational use of nasal decongestants. Among the key risks highlighted by the interviewees were the "addiction", the rebound effect, damage to the nasal mucosa and tachycardia, among others.

Approximately $37.8 \%(n=104)$ of students who use the decongestant make chronic use of medication. Among chronic users, $40.3 \%(n=42)$ are motivated to stop the use, while the remaining $59.6 \%(n=62)$ lacks this motivation.
The main reason for refusing to interrupt the chronic use of decongestants is the immediate comfort and relief of respiratory allergy symptoms the medicine offers, and the discomfort of the symptoms, mainly nasal obstruction. These results indicate a lack of knowledge on the risks of the chronic use of nasal decongestants, or a perception that the benefits outweigh the adverse effects.

The second questionnaire was administered to 165 students who were in the last year of a health care course. Through the information provided, we have obtained a mean $3.46 \pm 0.08$ in the five-point Likert-type intensity scale. Table $\mathrm{V}$ shows the corresponding mean level of knowledge of academic health care contained in assessment tool II.

The lowest mean scores by respondents are associated with questions regarding the prescription of vasoconstrictors and the possibility of poisoning in children. Several studies have detected psychosis in children as a result from the use of decongestants, ceasing with the discontinuation of the drug (Balbani et al., 1997). Hence, the fact that decongestants can contribute to risk for children did not influence the users because only few participants knew about this kind of risk. Some studies also show that the high frequency of intoxication can be explained by the difficulty of administering nasal drops to children, who normally do not accept this sort of medication. As a consequence, parents often administer higher doses to ensure that the desired effect occurs (Balbani et al., 1997). One possibility to prevent these cases could be a coordinated action, by health care professionals and educators, to educate and raise awareness on the proper use of these drugs (Balbani et al., 2004).

Many students stated that nasal decongestants should be only available on prescription. The fact that the drugs are available without prescription may lead users to think that their use or abuse is free of risks or side effects (Balbani et al., 2004).

Despite these results, the study found higher mean scores for the following academic affirmative: "Nasal hygiene can be made by means of nasal instillation of saline. It is an adjuvant form of treatment, simple and cheap, reduces the use of other medications, and should always be recommended".

\section{CONCLUSION}

From the results presented, we have concluded that the majority of respondents used or had been using nasal decongestants. A substantial share of participants who chronically used them was not motivated to stop using the drug, although prolonged use leads to serious complications. 
TABLE V - Statements contained in the assessment tool to analyze the level of knowledge of students from the last year of health care courses

Affirmative related to decongestants

1 - Decongestants relieve the symptoms of congestion and rhinitis associated with the common cold. They have little effect on itching, rhinorrhea and sneezing.

2 - Because they cause rebound congestion when used for more than 5 days, decongestants should not be used for the treatment of chronic rhinitis, except to assess their exacerbations.

3 - The use of a nasal decongestant is a symptomatic treatment, but it is also used on an inflammatory basis.

4 - The pediatric population is particularly susceptible to poisoning by drugs and systemic decongestants.

5 - The decongestants that are particularly useful in acute rhinitis, due to their more selective site of activity, tend to be excessively used by patients, resulting in rebound congestion.

6 - The nasal decongestant is used to treat allergic rhinitis, a disease that affects about $10 \%$ to $20 \%$ of the world population and more than $15 \%$ to $25 \%$ of children and adolescents.

7 - In practice, we see that certain patients commonly associate systemic decongestants with looking for a faster relief of symptoms. This association presents no risk of poisoning to the patient.

8 - In practice, we see that certain patients associate systemic decongestants with looking for a faster relief of the symptoms of nasal obstruction, and fail to calculate the poisoning effect.

9 - The use of systemic nasal decongestants should be limited in patients with prostate changes, hypertension, ischemic heart diseases, glaucoma, seizure disorders, hyperthyroidism, and difficulties in urinating.

10 - The topical agents are not effective because they are only weakly absorbed by the systemic circulation.

11 - A bottle of nasal decongestant medicine can be used by more than one person because there is no spread of infection.

12 - Decongestants are among the major classes of drugs responsible for poisoning and death of children under five years of age.

13 - Topical decongestants do not lead to nasal dryness and ulceration of the nasal mucosa.

14 - Nasal hygiene can be made by means of nasal instillation of saline. It is an adjuvant form of treatment, simple and cheap, and reduces the use of other medications.

15 - The best form of using topical nasal decongestants is to tilt one's head back, dripping drops in the amount indicated. The drug is absorbed shortly after returning to the previous position. mean \pm SEM

$3.54 \pm 0.09$

$3.78 \pm 0.09$

$3.05 \pm 0.11$

$3.64 \pm 0.09$

$4.01 \pm 0.08$

$3.72 \pm 0.08$

$3.54 \pm 0.11$

$2.76 \pm 0.11$

$3.84 \pm 0.09$

$3.47 \pm 0.10$

$4.06 \pm 0.11$

$2.88 \pm 0.09$

$2.95 \pm 0.10$

$4.35 \pm 0.08$

$2.39 \pm 0.11$
Moreover, the students' level of knowledge was considered insufficient, which may indicate that patients will not be sufficiently educated in the future, probably preventing the abuse to be diminished by a future generation of health care professionals. Therefore, coordinated actions are necessary in order to improve awareness on the proper use of nasal decongestants among health care students.

\section{REFERENCES}

ARNOLD, J.E. Upper respiratory tract. J. Pediatr., v.147, p.1052-1061, 1992.

ARRAIS, P.S.D.; BARRETO M.L.; COELHO, H.L.L. Aspectos dos processos de prescrição e dispensação de medicamentos na percepção do paciente: estudo de base populacional em Fortaleza, Ceará, Brasil. Cad. Saude Publica, v.23, p.927$937,2007$.
ARRAIS, P.S.D.; COELHO H.L.L.; BATISTA, M.C.D.S.; CARVALHO, M.L.; RIGHI, R.E.; ARNAU, J.M. Perfil da automedicação no Brasil. Rev. Saude Publica, v.32, p.7177, 1998.

BALBANI, A.P.S.; DUARTE, J.G.; MONTOVANI, J.C. Análise retrospectiva da toxicidade de gotas otológicas, medicamentos tópicos nasais e orofaríngeos registrada na Grande São Paulo. Rev. Assoc. Med. Bras., v.50, p.433-438, 2004.

BALBANI, A.P.S.; MION, O.G.; MELLO Jr, J.F.; BUTUGAN, O. Atualização em rinites. Rev. Bras. Med., v.59, p.2-13, 2002.

BALBANI, A.P.S.; NASCIMENTO, E.V.; SANCHEZ, T.G.; JÚNIOR, J.F.M.; BUTUGAN, O.; DUARTE, J.G. Tratamento da rinite alérgica em crianças: prescrição leiga de medicamentos e intoxicações. Pediatr. (São Paulo), v.19, p.249-256, 1997. 
BALBANi, A.P.S.; SANCHEZ, T.G.; BUTUGAN, O. Tratamento da sinusite em crianças nas farmácias do interior de São Paulo. Rev. Paul. Pediatr., v.14, p.158-162, 1996.

BALBANI, A.P.S.; SANTOS Jr., R.C.; SANCHEZ, T.G.; BUTUGAN, O. Um estudo sobre a prescrição de medicamentos em farmácias: sinusites. Rev. Bras. Otorrinolaringol., v.62, p.241-244, 1996.

BARROS, J.A.C. A atuação dos balconistas de farmácia: ajudando a promover o uso racional de medicamentos. $J$. Bras. Med., v.73, p.120 -127, 1997.

BRICKS, L.F. Medicamentos utilizados em crianças para tratamento do resfriado comum: risco vs. benefícios. $J$. Pediatr., v.17, p.72-78, 1995.

BRICKS, L.F.; SIH, T. Medicamentos controversos em otorrinolaringologia. J. Pediatr., v.75, p.11-22, 1999.

CAMPOS, J.A.; OLIVEIRA, J.S.; COSTA, D.M.; MACHADO, C.D.; ALVARENGA, J.R.U; TORRES, L.O.; FERREIRA, M.T.; LADEIRA, R.M.; CANÇADO, R.L. Prescrição de medicamentos por balconistas de 72 farmácias de Belo Horizonte/MG em maio de 1983: riscos de acidentes. $J$. Pediatr., v.59, p.307-312, 1985.

CASTRO, F.F.M. Rinite alérgica: modernas abordagens para uma clássica questão. 3.ed. São Paulo: Vivali, 2003. 295 p.

CORBOZ, M.; RIVELLI, M.; MINGO, G.; MCLEOD, R.; VARTY, L.; JIA, Y. Mechanism of decongestant activity of alpha 2-adrenocep-tor agonists. Pul. Pharmacol. Ther., v.21, p.449-454, 2008.

DOSHI, J. Rhinitis medicamentosa: what an otolaryngologist needs to know. Eur. Arch. Otorhinolaryngol., v.10, p.1-3, 2008.
GILMAN, A.; GOODMAN, L.S.; LIMBIRD, L.E.; HARDMAN, J.G. As bases farmacológicas da terapêutica. 9.ed. Rio de Janeiro: McGraw-Hill, 1996. 1436 p.

KENNEDY, D.L.; FORBES, M.B. Drug therapy for ambulatory pediatric patients in 1979. Pediatr., v.70, p.26-29, 1982.

SERVIDONI, A.B.; COELHO, L.; NAVARRO, M.L.; ÁVILA, F.G.; MEZZALIRA, R. Perfil da automedicação nos pacientes otorrinolaringológicos. Rev. Bras. Otorrinolaringol., v.72, p.83-88, 2006.

SILVA, T.; DAL-PIZZOL, F.; BELLO, C.M.; MENGUE, S.S.; SCHENKEL, E. P. Bula de medicamentos e a informação adequada ao paciente. Rev. Saude Publica, v.34, p.184-189, 2000 .

SMITH, D.G.; ARONSON J.K. Tratado de farmacologia clínica e farmacoterapia. 3.ed. Rio de Janeiro: Guanabara Koogan, 2004. 617 p.

VIERTLER, E.Y.C.; TESTA, J.R.G.; MORGADO, P.F.; FERREIRA, R.G. Irrigação intranasal: avaliação dos efeitos do uso de soluções hidroeletrolíticas na mucosa de ratos. Rev. Bras. Otorrinolaringol., v.69, p.491-495, 2003.

WECKX, L.L.M.; PONTES, P.A.L.; JUNIOR, L.K.; SIMOES, M.J.; NOVO, N.F.; YIN, L. Comportamento da glicose, dos lipídios totais e da fosfatase ácida no plasma de ratas prenhes tratadas com diferentes doses de nafazolina, administradas sob a forma de gotas nasais. Rev. Bras. Otorrinolaringol., v.49, p.11-14, 1983.

ZAFFANI, E.; RUFCA, G.F.; KAMIMURA, A.; MANIGLIA, J.V.; FERNADES, A.M. Perfil epidemiológico dos pacientes usuários de descongestionantes nasais tópicos do ambulatório de otorrinolaringologia de um hospital universitário. Arq. Ciênc. Saúde, v.14, p.95-98, 2007.

Received for publication on $21^{\text {st }}$ March 2011 Accepted for publication on $04^{\text {th }}$ October 2011 
